\title{
PENGARUH MULTIPLE MIKRO NUTRIEN (MMN) TERHADAP BERAT BADAN BAYI BARU LAHIR DI DESA PANDES KLATEN
}

\author{
Dwi Retna Prihati, Gita Kostania \\ Kementerian Kesehatan Politeknik Kesehatan Surakarta Jurusan Kebidanan
}

\begin{abstract}
MMN, Newborn Baby Weight. During pregnancy food is required with good quality and quantity to meet the nutritional needs of mother and baby. The low nutritional status of pregnant women during pregnancy can lead to various adverse effects for mothers and infants, such as those born with Low Birth Weight (LBW). LBW babies have a 10 to 20 times greater chance of dying than babies born with enough birth weight. Multiple Micro Nutrient (MMN) contains 15 types of vitamins and minerals most important for pregnant women, including vitamin A, vitamin $E$, vitamin $D$, vitamin B1, vitamin B2, niacin, Vitamin B6, vitamin B12, folic acid, vitamin $C, F e$, folic acid, Zink, Copper, Selenium, and Iodine. MMN is one of the nutrients to prevent the occurrence of anemia because in MMN there are factors forming Hemoglobin ie Fe, Vitamin B12 and folic acid. The availability of adequate hemoglobin makes the metabolic system work well. Lack of hemoglobin not only affects the health of the mother but also affects the health of the fetus it contains, including the growth of the fetal inhibition (such as weight, body length). The purpose of this study was to prove the effect of MMN on newborn weight in Pandes Klaten village. This type of research is a restrospective study with cross sectional design. The subjects of this study were BBL (newborn) whose mother consumed MMN during pregnancy. Different test using Independent T-test to compare control group and treatment group. Significant value in this study was $p<0.05$. The results of this study were no significant difference between birth weight between control group and MMN treatment group $(P=0.879)$. In conclusion MMN has no significant effect on newborn weight gain.
\end{abstract}

Keywords: MMN, Newborn Baby Weight

Abstrak: MMN, Berat Badan Bayi Baru Lahir. Pada masa kehamilan dibutuhkan makanan dengan kualitas dan kuantitas yang baik untuk dapat memenuhi kebutuhan gizi ibu dan bayinya. Rendahnya status gizi ibu hamil selama kehamilan dapat mengakibatkan berbagai dampak tidak baik bagi ibu dan bayi, diantaranya adalah bayi lahir dengan Berat Badan Lahir Rendah (BBLR). Bayi dengan BBLR mempunyai peluang meninggal 10 - 20 kali lebih besar daripada bayi yang lahir dengan berat lahir cukup. Multiple Mikro Nutrien (MMN) mengandung 15 jenis vitamin dan mineral yang paling penting untuk ibu hamil, diantaranya vitamin $A$, vitamin $E$, vitamin $D$, vitamin B1, vitamin B2, niacin, Vitamin B6, vitamin B12, folic acid, vitamin C, Fe, asam folat, Zink, Copper, Selenium, dan Iodium. MMN merupakan salah satu nutrisi untuk mencegah terjadinya anemia karena dalam MMN terdapat faktor pembentuk Hemoglobin yaitu Fe, Vitamin B12 dan asam folat. Ketersediaan hemoglobin yang cukup membuat sistem metabolisme dapat berjalan dengan baik. Kekurangan hemoglobin tidak hanya mempengaruhi kesehatan ibu tetapi juga mempengaruhi 
kesehatan janin yang dikandungnya, diantaranya pertumbuhan janin yang terhambat (seperti berat badan, panjang badan). Tujuan penelitian ini untuk membuktikan pengaruh pengaruh MMN terhadap berat badan bayi baru lahir di desa Pandes Klaten. Jenis penelitian ini adalah penelitian restrospektif dengan rancangan cross sectional. Subyek penelitian ini adalah BBL (bayi baru lahir) yang ibunya mengkonsumsi MMN selama hamil. Uji beda menggunakan Independent T-test untuk membandingkan kelompok kontrol dan kelompok perlakuan. Nilai signifikan dalam penelitian ini adalah $p<0,05$. Hasil penelitian ini adalah tidak ada perbedaan berat badan bayi baru lahir yang signifikan antara kelompok kontrol dan kelompok perlakuan MMN $(\mathrm{P}=0,879)$. Kesimpulannya MMN tidak berpengaruh signifikan terhadap kenaikan berat badan bayi baru lahir.

Kata Kunci: MMN, Berat Badan Bayi Baru Lahir

\section{PENDAHULUAN}

Pada masa kehamilan dibutuhkan makanan dengan kualitas dan kuantitas yang baik untuk dapat memenuhi kebutuhan gizi ibu dan bayinya. Rendahnya status gizi ibu hamil selama kehamilan dapat mengakibatkan berbagai dampak tidak baik bagi ibu dan bayi, diantaranya adalah bayi lahir dengan Berat Badan Lahir Rendah (BBLR). Bayi dengan BBLR mempunyai peluang meninggal 10 - 20 kali lebih besar daripada bayi yang lahir dengan berat lahir cukup. (Chairunita, Hardiansyah, Dwiriani, 2006).

Zat besi $(\mathrm{Fe})$ adalah salah satu faktor pembentuk hemoglobin yang berfungsi mengangkut $\mathrm{O} 2$ keseluruh sel. Ketersediaan hemoglobin yang cukup membuat sistem metabolisme dapat berjalan dengan baik dan bertambahnya berat badan ibu dan anaknya. Kekurangan hemoglobin tidak hanya mempengaruhi kesehatan ibu tetapi juga mempengaruhi kesehatan janin yang dikandungnya, diantaranya pertumbuhan janin yang terhambat (seperti berat badan, panjang badan), kelainan morfologi janin, bahkan kematian janin.(Wiknjosastro, 2008; Cuningham, 2006). Kadar hemoglobin dibawah 8 gram/ $100 \mathrm{ml}$ pada ibu dapat meningkatkan resiko ensefalopati neonatal di negara-negara berkembang (Ellis et all, 2007). Konsentrasi feritin serum yang rendah, khususnya dalam trimester pertama, berkaitan dengan peningkatan vaskularisasi serta ukuran plasenta, retardasi pertumbuhan intrauteri dan berat lahir yang rendah (Hindmarsh et al, 2008).

Ibu hamil yang mengalami anemia akan lebih rentan mengalami perdarahan intrapartum dan postpartum. Anemia merupakan keadaan dimana masa eritrosit dan atau masa hemoglobin yang beredar tidak memenuhi fungsinya untuk menyediakan oksigen bagi jaringan tubuh. Anemia dalam kehamilan adalah kondisi ibu dengan kadar haemoglobin dibawah 11 gr\% pada trimester I dan II atau kadar $<10,5$ gr\% pada trimester III (Azwar, 2006).

World Health Organization (WHO) melaporkan bahwa terdapat 52\% ibu hamil yang mengalami anemia di negara berkembang. Prevalensi anemia pada ibu hamil di Indonesia menurut Survey Kesehatan Rumah Tangga (SKRT) masih cukup tinggi yaitu 40,1\%. Hasil Riset Kesehatan Dasar (Riskesda) menunjukkan $80,7 \%$ perempuan usia 10 - 
59 tahun (termasuk ibu hamil) telah mendapatkan tablet tambah darah yang mengandung besi-asam folat. Belum ada penelitian terkait cakupan pemberian penambah darah. Meskipun demikian angka kejadian anemia pada ibu hamil masih mencapai 40-50\%, artinya 5 dari 10 ibu hamil di Indonesia mengalami anemia (Kemenkes RI, 2013).

Sebagai bagian dari strategi global untuk mencegah kekurangan mikronutrien pada ibu hamil, UNICEF merekomendasikan bahwa penggunaan Multi Mikro Nutrien (MMN) untuk suplemen prenatal sebagai program pendahuluan di negara berkembang. Sejak tahun 2014 Dinas Kesehatan Kabupaten Klaten mendistribusikan multi mikronutrien pada Puskesmas-Puskesmas di wilayah kabupaten Klaten sebagai pengganti tablet Fe-Asam Folat kepada ibu hamil untuk mengatasi anemia. Multi mikronutrien mengandung 15 jenis vitamin dan mineral yang paling penting untuk ibu hamil, diantaranya vitamin A, vitamin $\mathrm{E}$, vitamin $\mathrm{D}$, vitamin $\mathrm{B} 1$, vitamin B2, niacin, Vitamin B6, vitamin B12, folic acid, vitamin $\mathrm{C}, \mathrm{Fe}$, asam folat, Zink, Copper, Selenium, dan Iodium.

Berdasarkan studi pendahuluan yang kami lakukan, pada tahun 2015 terdapat sebanyak $26,6 \%$ ibu hamil yang mengalami anemia ringan (8-11 gr\%) dan $0,74 \%$ anemia berat $(<8$ gr\%) dari 34 Puskesmas di Kabupaten Klaten. Dari data tersebut, Puskesmas yang menduduki peringkat terbanyak untuk ibu hamil anemia berada di Puskesmas Wedi, yaitu sebanyak 48,8\% ibu hamil mengalami anemia (DKK Klaten, 2015).

Cakupan pemberian MMN di Puskesmas Wedi tahun 2015 sebesar 83\%. Program yang sudah berjalan sebelumnya adalah pemberian $\mathrm{Fe}$-Asam folat.
Cakupan ini belum mencapai standar nasional sebesar 90\%, maka perlu dilakukan upaya untuk mencapai target yang ditetapkan tersebut. Belum diketahui faktor penyebab tidak tercapainya target program suplementasi MMN ini. Oleh karena itu, perlu dilakukan evaluasi program pemberian tablet MMN di Puskesmas Wedi Kabupaten Klaten, dengan pendekatan teori sistem, meliputi input, proses dan output (Azwar, 1996).

\section{METODE PENELITIAN}

Jenis penelitian ini adalah penelitian restrospektif dengan rancangan cross sectional. Subyek penelitian ini adalah BBL (bayi baru lahir) yang ibunya mengkonsumsi MMN selama hamil. Jumlah kelompok kontrol (BBL yang ibunya tidak mengkonsumsi MMN) sebanyak orang, dan kelompok perlakuan (BBL yang ibunya mengkonsumsi MMN) sebanyak 9 orang. Data dianalisis secara statistik menggunakan SPSS 17. Uji Normalitas data dengan Saphiro Wilks. untuk membandingkan kelompok kontrol dan kelompok perlakuan menggunakan Independent T-test. Nilai signifikan dalam penelitian ini adalah $p<0,05$.

\section{HASIL PENELITIAN}

Pada penelitian ini, perbedaan berat badan bayi baru lahir antara kelompok kontrol dan kelompok yang mengkonsumsi MMN di desa Pandes Klaten ditunjukkan pada tabel berikut ini:

\section{Tabel 1} Berat badan BBL

\begin{tabular}{lllll}
\hline Kelompok & $\begin{array}{l}\text { Mean } \\
(\mathrm{SD})\end{array}$ & Min & Max & $\mathrm{P}$ \\
\hline $\mathrm{K}$ & 3,11 & 2500 & 3900 & 0,879 \\
$\mathrm{P}$ & $\begin{array}{l}(4,48) \\
3,29\end{array}$ & 2800 & 3700 & \\
& $(3,08)$ & & & \\
\hline
\end{tabular}


Dari tabel diatas terlihat adanya selisih mean antara kelompok kontrol dan kelompok perlakuan yaitu sebesar 0,18 gr. Nilai $\mathrm{P}$ yang didapatkan dari uji independent $\mathrm{T}$-Test adalah 0,879 yang artinya tidak terdapat beda yang signifikan antara kelompok kontrol dan kelompok perlakuan MMN

\section{PEMBAHASAN}

Berdasarkan rata-rata (Mean) dapat dilihat bahwa MMN dapat menaikkan berat badan BBL sebanyak 0,18 gram. Hal ini dikarenakan dalam MMN mengandung nutrisi yang banyak khususnya $\mathrm{Fe}$, asam folat dan B12. Multiple Mikro Nutrien (MMN) mengandung 15 jenis vitamin dan mineral yang paling penting untuk ibu hamil, diantaranya vitamin $\mathrm{A}$, vitamin $\mathrm{E}$, vitamin $\mathrm{D}$, vitamin $\mathrm{B} 1$, vitamin $\mathrm{B} 2$, niacin, Vitamin B6, vitamin B12, folic acid, vitamin $\mathrm{C}, \mathrm{Fe}$, asam folat, Zink, Copper, Selenium, dan Iodium. MMN merupakan salah satu nutrisi untuk mencegah terjadinya anemia karena dalam MMN terdapat faktor pembentuk Hemoglobin yaitu Fe, Vitamin B12 dan asam folat Zat besi diperlukan untuk bahan pembentukan hemoglobin, sedangkan vitamin $\mathrm{C}$ dapat membuat zat besi dalam daun kelor terserap tubuh dengan maksimal saat dikonsumsi. Secara teori Proses absorbsi besi dalam usus terdiri dari 3 fase yaitu fase luminal, fase mucosal, dan fase sistemik atau korporeal (Bakta, 2000). Pada fase luminal ikatan besi dari bahan makanan (kelor) dilepaskan atau dirubah menjadi bentuk terlarut dan terionisasi. Kemudian besi dalam bentuk feri $(\mathrm{Fe} 3+)$ direduksi menjadi bentuk fero $(\mathrm{Fe} 2+)$ sehingga siap diserap usus. Dalam proses ini getah lambung memegang peranan penting. Absorbsi paling baik terjadi pada duodenum dan jejenum proksimal. Hal ini dihubungkan dengan jumlah reseptor pada permukaan usus dan $\mathrm{pH}$ usus. Dalam 100 gram serbuk kelor mengandung banyak asam amino yang disini dapat membantu mencegah terjadinya proses polimerisasi dan presipitasi besi. Selain itu, pada kelor terdapat vitamin c (asam askorbat) yang merupakan bahan pemacu absorbsi besi yang sangat kuat yang berfungsi sebagai reduktor yang dapat mengubah feri menjadi fero, mempertahankan $\mathrm{pH}$ usus tetap rendah sehingga mencegah presipitasi besi dan bersifat sebagai monomeric chelator yang membentuk iron-ascorbate chelate yang lebih mudah diserap oleh tubuh. Setelah itu, besi diserap secara aktif melalui reseptor. Jika dosis terlalu besar besi akan masuk secara difusi pasif. Dalam sel enterosit besi akan diikat oleh suatu karier protein spesifik dan ditransfer melalui sel ke kapiler atau disimpan dalam bentuk ferritin dalam enterosit kemudian dibuang bersamaan dengan deskuamasi epitel usus. Pada fase sistemik, besi yang masuk ke plasma akan diikat oleh apotransferin menjadi transferrin dan diedarkan ke seluruh tubuh, terutama ke sel eritroblast dalam sumsum tulang. Semua sel mempunyai reseptor transferrin pada permukaannya. Transferrin ditangkap oleh reseptor ini dan kemudian melalui proses pinositosis (endositosis) masuk dalam vesikel (endosome) dalam sel. Akibat penurunan $\mathrm{pH}$, besi, transferrin, dan reseptor akan terlepas dari ikatan. Besi akan dipakai oleh sel sedangkan reseptor dan transferrin dikeluarkan untuk dipakai ulang. Selanjutnya zat besi $(\mathrm{Fe})$ bersamasama dengan asam folat dan vitamin B12 akan berproses untuk menjadi hemoglobin. Hemoglobin yang berfungsi mengangkut $\mathrm{O} 2$ keseluruh sel. 
Ketersediaan hemoglobin yang cukup membuat sistem metabolisme dapat berjalan dengan baik (Robert K, 2006). Dari uji Independent T-test didapatkan nilai $\mathrm{p}=0,879$ yang berarti, tidak terdapat perbedaan berat badan bayi baru lahir yang bermakna antara kelompok kontrol dan kelompok perlakuan walaupun rerata memperlihatkan bahwa MMN dapat menaikkan berat badan BBL sebanyak 0,18 gram .

\section{KESIMPULAN DAN SARAN}

1. Berdasarkan nilai rata-rata (mean), MMN dapat menaikkan berat badan bayi baru lahir sebesar 0,18 gram.

2. Tidak terdapat perbedaan berat badan bayi baru lahir yang bermakna antara kelompok kontrol dan kelompok yang diberi perlakuan MMN ( $\mathrm{p}=0,879$ )

\section{DAFTAR RUJUKAN}

Azwar, Azrul. 2006. Naskah Pertemuan Advokasi Program Perbaikan Gizi Menuju Keluarga Sadar Gizi:
Kecenderungan Masalah Gizi dan Tantangan di Masa Datang. Dirjen Bina Kesmas Depkes, Jakarta.

Cunningham G.F., Gant N.F., Leveno K.J., et all. 2006. Gangguan Pertumbuhan Janin Dalam Buku Obstetri Williams vol 1 edisi 21. Jakarta; EGC:. hal 825-850

Dinas Kesehatan Klaten. 2015. Petunjuk Tehnis MMN. DKK Klaten, Klaten.

Kemenkes RI. 2013. Multiple Micro Nutriens Program. Jakarta.

Robert K. Murray. 2006. Sel Darah Merah Dan Putih Dalam Buku Biokimia Harper edisi 27 . Jakarta: EGC;. hal 636-652

Wiknjosastro Gulardi H. 2008. Pertumbuhan Janin Terhambat Dalam Buku Ilmu Kebidanan. Jakarta: Bina Pustaka;. hal 696717 